Article

\title{
Decentralization and REDD+ in Brazil
}

\section{Fabiano Toni}

Centro de Desenvolvimento Sustentável Universidade de Brasília, Campus Universitário Darcy Ribeiro, CET/CDS, Bloco C, Brasília, DF, CEP 70904-970, Brasil; E-Mail: ftoni@unb.br; Tel.: +55-61-3107-6000; Fax: +55-61-3107-5972

Received: 15 November 2010; in revised form: 27 December 2010 / Accepted: 29 December 2010 / Published: 5 January 2011

\begin{abstract}
Recent discussions on REDD+ (Reducing Emissions from Deforestation and Forest Degradation, plus conservation, sustainable management of forests and enhancement of forest carbon stocks) have raised optimism about reducing carbon emissions and deforestation in tropical countries. If approved under the United Nations Framework Convention on Climate Change (UNFCCC), REDD+ mechanisms may generate a substantial influx of financial resources to developing countries. Some authors argue that this money could reverse the ongoing process of decentralization of forest policies that has spread through a large number of developing countries in the past two decades. Central states will be accountable for REDD+ money, and may be compelled to control and keep a significant share of REDD+ funds. Supporters of decentralization argue that centralized implementation of REDD+ will be ineffective and inefficient. In this paper, I examine the relation between subnational governments and REDD+ in Brazil. Data show that some state governments in the Brazilian Amazon have played a key role in creating protected areas (PAs) after 2003, which helped decrease deforestation rates. Governors have different stimuli for creating PAs. Some respond to the needs of their political constituency; others have expectations to boost the forest sector so as to increase fiscal revenues. Governors also have led the discussion on REDD+ in Brazil since 2008. Considering their interests and political power, REDD+ is unlikely to curb decentralization in Brazil.
\end{abstract}

Keywords: Brazil; Amazonia; tropical forests; decentralization; protected areas; REDD+; subnational governments; federalism 


\section{Introduction}

The combined effects of clear-cutting, forest regrowth on abandoned land and logging, are estimated to have accounted for 10-25 per cent of global, human-induced carbon emissions in the 1990s [1]. The Kyoto Protocol gave developing countries such as Brazil and Indonesia, which are responsible for a large share of global deforestation, little incentive to cut carbon emissions. Since the mid-2000s, scientists, activists and policymakers have been pressing for the creation of international mechanisms to compensate developing countries that choose to reduce their emissions from deforestation. Current discussions focus on a set of policies known as 'REDD+' (Reducing Emissions from Deforestation and Forest Degradation, plus conservation, sustainable management of forests and enhancement of forest carbon stocks).

Some analysts claim that REDD+ projects have the potential to generate enough money to end deforestation in countries such as Brazil [2]. Others see REDD+ money as a threat to a policy trend that has been positively affecting forests and forest dwellers for the past 25 years, that is, political decentralization [3]. Discussions concerning the implementation of REDD+ tend to consider either project-based or national-based implementation. Most proposals for REDD+ favor the latter approach, as it permits operations on a larger scale. Furthermore, it requires governments to implement national carbon accounting systems, to control leakage and to distribute the benefits of REDD+ to relevant stakeholders [4]. At first glance, therefore, recentralization could be considered a requisite for countries to receive REDD+ funds.

This paper is not aimed at discussing the questions related to either the effectiveness of REDD+ as a mechanism to curb deforestation, nor to the alleged advantages of decentralization for forest protection. Rather, I examine the interplay between REDD+ and decentralization. Two main questions are addressed here. First: What implications REDD+ may have for decentralization in the forestry sector? Second: Does decentralization pose additional challenges for the implementation of REDD+? In addressing these questions, it is important to remember that a wide range of formal and informal institutional arrangements are in place in the tropical countries that will most likely benefit from REDD+.

Our main hypothesis is that existing institutional arrangements, along with the incentives that REDD+ mechanisms provide, may affect decentralization trends in developing countries. Here, 'institutional arrangements' refers to the balance of power between the different levels of government, the political preconditions for decentralization of forest policies (i.e., trends before REDD+) and the existing technical capacity to deal with the complexities of REDD+ at subnational levels of government.

This paper argues that REDD+ will change the structure of incentives for subnational policymakers, particularly governors in a federal state such as Brazil, encouraging them to pursue further decentralization, control deforestation and restore degraded forests in order to keep receiving REDD+ funds. The main beneficiaries of these activities will vary depending on each state's main economic activities as well as on the governor's constituency. How this type of decentralization will affect municipal governments, however, remains an open question. Mayors are lagging behind governors in discussions concerning REDD+ and climate change in general, and wield much less influence over the federal government in such negotiations. 


\section{REDD+ and Decentralization-Framework of Analysis}

Decentralization can have many different meanings. In this paper, I use the term to refer to the transfer of powers and resources from central to democratically elected subnational governments; this has been commonly called either democratic decentralization or devolution [5-7]. Reasons given in favor of decentralization include that it: (1) Increases local participation and local democracy; (2) improves efficiency and equity of service delivery; and (3) strengthens local government [8].

Local governments are important, because efficiency in the provision of government services (land use monitoring) is crucial for avoiding carbon leakage. This is a key point in large countries such as Brazil, where the central government cannot possibly monitor land use across its entire territory. This lack of efficiency explains why the country has so far failed to control deforestation, despite its very restrictive legislation. The involvement of local governments can considerably lower transaction costs for monitoring land use. However, as has been frequently argued, subnational governments usually lack the capacity and incentives to do this kind of job [9,10]. REDD+ money can change both factors at once. If governors and mayors perceive that they can reap economic and political benefits from payments for environmental services, they will likely engage in more extensive land use monitoring. Moreover, REDD+ money is expected to provide the means for strengthening government capacity at state and municipal levels.

This is not to say that REDD+ will necessarily involve local people in decision making. However, the involvement of municipal and state governments in the planning of a national REDD+ policy will grant it legitimacy and will lower resistance at the local level. Moreover, subnational governments may be more prepared to tackle the specific causes of deforestation, which vary across locations [4]. The distribution of REDD+ benefits to local governments may also have a positive impact for local people, as state and municipal governments provide such fundamental services as education and health care. However, groups that are marginalized at the local level, such as indigenous people in Brazil, may suffer most under a decentralized REDD+ mechanism. The federal government is responsible for demarcating indigenous lands, and is the formal owner of those lands. However, indigenous people have full rights to the natural resources in their lands, which includes its carbon [11]. Considering that indigenous lands in the Amazon are the least deforested areas in the region, particularly on the agricultural frontier [12] under a centralized REDD+ mechanism, indigenous people may be compensated for keeping carbon stocks in their lands.

Existing REDD+ proposals include elements that call for both recentralization and decentralization. Planning and executing projects and collecting compensation the central or subnational level have advantages and disadvantages. Larson and Ribot [13] summarize the options in terms of their effectiveness, efficiency and equity. Central governments may be better equipped to address macro driving forces of deforestation at a lower transaction cost, due to economies of scale, and have potential to protect marginalized groups. Local elected governments, in contrast, may achieve greater acceptance of rules if local citizens participate, and may provide differentiated incentive payments that consider the diversity of local land use systems. However, they point out that at a local level, benefits may be captured by local elites.

Similarly, Irawan and Tacconi [4] argue that centralized REDD+ may require fewer resources and less time for project development, and are easier to monitor, but may face greater resistance from local 
governments. Also, they have higher risks of incorrectly targeting the causes of deforestation. Decentralized implementation may meet with more acceptance from local governments and promote capacity building of local actors. However, more resources and time are required for project development.

The studies by Irawan and Tacconi and Larson and Ribot [4,13] highlight important differences between centralized and decentralized REDD+ mechanisms and clearly show the trade-offs between them. These are helpful findings, but decisions concerning how REDD+ policies will actually be implemented will not be based solely on transaction costs, effectiveness, equity and other desirable features of a public policy. Rather, the politics and existing institutions will affect any decisionmaking. Therefore, I propose a framework of analysis to study the impact of REDD+ on decentralization that considers those factors.

For the sake of clarity, although at the expense of precision, I assume that countries may have weak or strong institutional capacity in forest policies at the subnational level. 'Institutional capacity' here refers to: (1) The human, material and financial resources needed to engage in forest policy and forest management activities. Such activities include, but are not limited to, planning and monitoring land use, and issuing land clearing and logging permits; (2) the legal framework that regulates the distribution of competences amongst government levels; (3) the balance of power amongst different government levels. Accordingly, I assume that REDD+ mechanisms either fulfill optimistic expectations or fall well short of them. The interplay of the two variables produces four scenarios, as set out in Table 1.

Table 1. Interplay between institutional capacity at subnational level and availability of REDD resources.

\begin{tabular}{ccc}
\hline & \multicolumn{2}{c}{ Availability of REDD resources } \\
\hline Institutional capacity & High & Low \\
\hline Strong & Further & Atomization \\
Weak & $\begin{array}{c}\text { decentralization/polycentric } \\
\text { governance systems } \\
\text { Recentralization }\end{array}$ & Business as usual \\
\hline
\end{tabular}

REDD+ resources that do fulfill optimistic expectations may in fact present a challenge to decentralization, because central governments will feel compelled to reap most, if not all, the financial benefits of reducing carbon emissions from deforestation and forest degradation. There will be competition for resources. Central governments usually are ahead of subnational governments, because they already have prerogatives over forest policies and superior technical capacity. REDD+ implementation will place new demands on forest authorities, such as for reliable baseline data, subsequent quantitative reports on emission reductions and control of leakage. In theory, these demands would benefit from economies of scale, coordination and standardization [3,4,13]. Moreover, under formal international agreements, national states will be accountable for carbon emissions. This is not necessarily a grim scenario for decentralization. If the inefficiency issues become salient, central governments may be compelled to strengthen local governments and decentralize; otherwise, they may fail to meet their commitments and wind up losing a valuable source of funds. Even equity issues may 
emerge at some point and have a similar effect. If the local population feels excluded from the benefits of REDD+, or harmed by land use restrictions, they may sabotage efforts to control deforestation.

Where institutional conditions are strong, central and subnational governments may reach a compromise and share both the benefits of REDD+ money and the responsibilities of monitoring and enforcing carbon emission reductions related to land use. In this case, even if there is some inequality in the distribution of benefits, decentralization trends will be reinforced. This scenario would be highly desirable, especially if there is capacity building at all levels of government, and if there are checks and balances between them. In this case, REDD+ projects may be sensitive to local needs and constraints, and subnational governments may tackle problems that are specific to their territory. At the same time, the central government may neutralize drivers of deforestation that operate at larger scales, and monitor the activities of subnational governments to avoid local elite capture of power and resources. This would constitute a polycentric model of forest governance under REDD+ mechanisms. It is clear, however, that institutional capacity at the central level will be crucial for both scenarios in which REDD+ resources are plentiful. To perform all tasks required to implement REDD+, central governments will necessarily have to have technical capacity, to operate in a clear legal framework, and have political power to negotiate and enforce rules at the domestic level.

Where REDD+ resources fall short of expectations, intergovernmental competition will not be fierce. If institutional capacity is weak and resources scarce-the business-as-usual scenario-local governments will not collaborate with national environmental authorities in centrally controlled projects. There are unlikely to be many relevant projects, and deforestation trends will not change significantly. By contrast, where institutional conditions are strong, some local governments may engage in REDD+ projects if they already have an environmental agenda. As I show below, some states and even municipalities in Brazil are already taking part in such projects. Yet, even though they benefit from these projects, this scenario of atomization offers little likelihood that the drivers of deforestation—road building, cattle ranching, illegal logging and the expansion of soybean plantations-will be curbed. However, this voluntary engagement of subnational governments in REDD+ projects is clear evidence of the positive effects of decentralization on REDD+.

\section{Applying the Framework: Brazilian Institutions in Context}

In this section I show that Brazil has a political and institutional context that is conducive to a decentralized or polycentric model of REDD+ implementation. First, I discuss the broader institutional framework, that is, the nature of Brazilian federalism, which grants power to governors to prevent excessive centralization of prerogatives and resources in the federal government. In the second part of the section, I discuss how the legal framework concerning forests allows great participation of subnational governments in forest policies. Next, I present the organizational environment and forestry framework, which creates opportunities for both cooperation and competition amongst the federal and subnational governments. Finally, I discuss some recent institutional developments aimed at strengthening the forest sector, and putting more forests under protection in the Amazon. These changes follow the principles of the existing legal framework and allow further participations of subnational governments. 


\subsection{Broader Institutional Framework: Contentious Federalism}

Brazil is a federation of 26 states and a federal district, divided into 5,561 municipalities. Each government level has its own executive and legislative branch. The legislators at all three levels, as well as the heads of their executive branches (president, governors and mayors), are directly elected by popular vote. Brazil's political history is marked by continual changes in the relationships between these three government levels, which at times have promoted decentralization and at others centralization [14]. In general, the periods of loss of municipal power and autonomy correspond to the interruption of the democratic system, such as during the Getúlio Vargas dictatorship (1937-1945) and the military regime (1964-1984). In addition, decentralization must be understood in the light of Brazil's peculiar federal system, which is marked by constant disputes between the states and the central government.

Although the Brazilian federal system drew on the U.S. system, the two have significant differences. It has been argued that the U.S. Federation was created for the existing states to 'come together' in a union, whereas the Brazilian Federation was created to hold together administrative units that otherwise could easily fragment, as had occurred in Spanish America [15]. In other words, in Brazil a central government preceded the states. Rather than surrendering power to a central state, the then provinces claimed power and further autonomy from the central state during the transition from an empire to a republic, in 1889 [16]. This new arrangement ensured state elections and enabled local elites to form political parties, which could run in national elections, or simply be used as a bargaining tool in dealings with the federal government. Although current legislation requires political parties to have national representation, governors still hold significant power over federal deputies elected in their states. Brazilian politics is marked by constant friction between state governments and the federal government, as well as by competition amongst states, particularly concerning the distribution of fiscal revenues (Box 1).

\subsection{The Legal Framework}

Brazil's 1988 Constitution places environmental issues in the sphere of common and convergent competencies between the federal, state and municipal governments. This means that none of the three has exclusive power to legislate or implement environmental policy. The Constitution specifically establishes that all three levels have a duty to preserve 'an ecologically balanced environment', which explicitly includes forests [17]. The most important pieces of legislation related to forests are the Forest Code and the laws that establish the National System of Protected Areas (SNUC), not only because they are at the core of Brazilian efforts to protect ecological services, but also because they refer directly to decentralization of forest policies.

The 1965 Forest Code (Law No. 4771) is a set of laws regulating not only forestry but also land use in public and private areas. The code established the possibility of creating parks, reserves and public forests, and introduced the concepts of permanent conservation areas and legal reserves. The code thus established an obligation for owners to conserve at least 50 per cent of the forest cover on their properties as legal reserves. 
Box 1. Competition for oil royalties between Brazil's federal, state and municipal governments.

In 2009, Brazil was the world's sixteenth largest oil producer, owning proved reserves of about 12.6 billion barrels. Most of its oil comes from offshore drilling. The royalties from oil exploitation correspond to $10 \%$ of the net production, and are divided between those states adjacent to the oil platforms (22.5\%), adjacent municipalities (22.5\%), municipalities affected by oil loading and unloading operations (7.5\%), other municipalities (7.5\%) and the federal government (40\%). Adjacent municipalities and states receive the lion's share of the royalty because, in theory, they have to provide the inland infrastructure and services that facilitate exploitation. This formula was set up when Brazil had little oil and prices were quite stable. However, in 2007, the Brazilian oil company Petrobras announced the discovery of massive amounts of ultra-deep water oil. If expectations were met, the country's proved reserves could exceed 50 billion barrels.

Following the announcement, the federal government sent a bill to the Chamber of Deputies, aimed at reforming the oil sector to enable the Union to increase its involvement in Petrobras. In an opportunistic move, some chamber members amended the bill to change the distribution of royalties. At the time the finding was announced, oil prices were peaking and the royalties seemed too attractive for states to ignore. Moreover, as the fields are some $400 \mathrm{~km}$ off the southeast coast, spanning an area of $800 \mathrm{~km} 200 \mathrm{~km}$, the granting of privileges to adjacent states and municipalities became hard to defend. A new bill was sent to the Chamber of Deputies, proposing the royalties be divided between all states and municipalities according to their share of the country's population. Under this new arrangement, the few states that collect most of the royalties under the existing law would suffer severe losses.

After the bill passed in the Chamber of Deputies, the president was expecting the Senate to veto it. However, with a general election scheduled for October 2010, most senators would not vote against a bill that could increase revenue for their home states. Not surprisingly, some representatives cornered the president with a proposal to reduce the federal government's share of royalties as a way to compensate for the losses inflicted on producing states. To avoid political damage in an election year, the bill was put aside. It is clear, however, that the states will exact a toll to change oil regulation.

To reduce the alarming rate of deforestation in the Brazilian Amazon, the federal government published a provisional measure in 2001, which is still in effect, that sought to increase the proportion of legal reserves from $50 \%$ to $80 \%$ of properties in that area. Another innovation of the 1965 Forest Code was to make forest management obligatory for timber extraction in native tropical forests. Nonetheless, 21 years passed before the government established forest management norms to regulate what was originally laid out in the code.

Law No. 9985 of 18 July 2000, which created the National System of Protected Areas, mentions the participation of municipalities in forest resource management. The SNUC covers all public protected areas, be they federal, state or municipal. According to the law, the three different government levels 
may create both 'strict use protected areas', in which natural resource exploitation is totally prohibited, and 'sustainable use protected areas', which can be exploited in accordance with a management plan.

The most common strict use protected areas (PAs) are parks, mainly national parks. Many states have delimited state parks, which are usually smaller than the national ones; there are very few municipal parks in the Amazon. The most common sustainable use PAs, are the federal extractive reserves. As I show in Section 6, states have significantly increased their participation in the creation of PAs in the past eight years.

Another important piece of legislation, the impacts of which remain to be felt, is the 2006 Public Forests Management Law (Law 11.284/2006), which regulates the use of public forests. The law considers three options for forest management: Direct management of a forest by public entities; forest set aside for local communities; and forest concessions for private companies. The law regulates the use of forests pertaining to the Union, states and municipalities, which are required to pass specific legislation if they are to manage their public forests. Even though the law implies a central regulatory control over forests, it opened opportunities for increased participation of subnational governments in forest management.

\subsection{Organizational and Bureaucratic Framework}

In 1972, inspired by the Stockholm Conference, Brazil created its first national environmental agency, SEMA. In 1981, a new law was passed creating the National Environmental Council (CONAMA), which included representatives both from state governments and from civil society. In the same year, the federal government also passed legislation introducing environmental licensing and environmental impact studies. Amidst a scenario of slow but steady democratization, legislators and SEMA succeeded in passing fairly decentralized legislation. Significant powers were devolved to states, which had their own environmental agencies [18]. However, contrary to the expectations of SEMA's bureaucrats and environmentalists, the government failed to approve a fund that could sustain more ambitious environmental programs.

Still understaffed and underfunded, in 1989, SEMA and CONAMA were merged with the Brazilian forestry (IBDF), fishing and rubber development agencies to form the Brazilian Institute for the Environment and Natural Resources (IBAMA), reporting directly to the president's office. In 1990, SEMA was again separated from IBAMA to become a policy and planning governmental agency, whereas IBAMA kept its executive authority. Although this change came at the beginning of the administration of the first democratically elected president after the military government, no effective measures towards decentralization were taken. On the contrary, the individualistic and flamboyant style of both the president and the SEMA secretary curtailed participation and led to a concentration of power in the federal government, particularly by weakening CONAMA.

In 1992, SEMA was merged with the Ministry of Science and Technology; then, in 1995, it gained its current status as the Ministry of the Environment. CONAMA also had its powers restored. Even though changes have been slow, and have generated political tensions, this last change inaugurated a period of increasing decentralization and participation in environmental policymaking. On the one hand, IBAMA has resisted the devolution of some of its powers to state governments. On the other hand, some states successfully demanded such devolution, and the federal government helped 
Amazonian states strengthen their environmental agencies. This help was provided mainly through the Brazilian Pilot Program to Conserve the Rainforest, a multilateral cooperation agreement between the G7 countries, the European Union, the Netherlands and Brazil. Launched in 1992, the PPG7 had a trust fund managed by the World Bank; donors had channeled US\$ 428 million to the fund as of mid-2009.

\subsection{Recent Developments}

As a result of the 2006 Public Forests Management Law, the federal government created the Brazilian Forest Service (SFB). The SFB's responsibilities include managing national forests, granting and overseeing concessions and keeping a national public forest register. The SFB has limited human and financial resources, and has only auctioned three concessions, which covered some 96,000 ha of the Jamari National Forest in the state of Rondônia. This number represents a tiny fraction of the 10 year target set by the SFB: 13 million ha out of a 43 million ha stock of public forest that can be put under concession regimes.

The aims of the Public Forests Management Law are to strengthen the forestry sector and to reduce illegal logging and land grabbing which are important drivers of deforestation. Some critics argue that concessions will ultimately mean privatization of public lands, and express doubts about the law's expected effects on forest protection. Even if such effects do eventuate, the slow pace of concessions is no match for the high average annual deforestation rate in Amazonia, which is close to $19,500 \mathrm{~km}^{2}$, although declining [2]. To protect the forest more effectively and to achieve Brazil's goal to reducing deforestation by 80\%, in 2002 the federal government launched the ARPA Project, an ambitious 12 year forest protection program. Since 2003, ARPA has created 44 new PAs, sheltering some 24 million ha. Although these are impressive numbers, Brazil is still behind on its commitment under the U.N. Convention on Biological Diversity to put 30\% of Amazonia's original surface under protection by the end of 2010.

On a different front, Brazil established the Amazon Fund, with an initial US\$ 1 billion pledge from the Government of Norway, under which Brazil will receive annual payments if it continues to reduce carbon emissions. The fund may be used to support research, law enforcement and other activities related to reducing deforestation, and also targets land users (private owners and communities), who will be compensated for reducing land clearing. The fund is considered a kick-off for REDD+ projects in Brazil [2].

Managing public forests and protected lands as well as issuing environmental licenses in a vast area such as Amazonia has proved challenging for Brazil's federal environmental organizations; however, increasingly, state governments have been stepping in to help carry out some of those tasks.

\section{State Governments and Forest Protection}

Brazil has reached a prominent position in terms of implementing protected areas since 2003 [19]. Even though many of those areas are left almost unattended after its formal implementation, their very presence has proven to be an effective tool to deter deforestation. A study comparing deforestation inside and outside PAs in the Amazon shows that deforestation was 1.7 (in extractive reserves) to 20 (in parks) times higher along the outside versus the inside of the PAs perimeters [12]. Another study corroborates this data. In the states of Mato Grosso, Pará, and Rondônia, which have the highest 
deforested proportion in the Amazon, the average deforested proportion inside PAs was respectively $3.5 \%$, $4.5 \%$, and $4.7 \%$. Outside those areas, the proportion reached $33.9 \%, 29.2 \%$, and $48.1 \%$ respectively. [20].

The expansion of PAs in the Brazilian Amazon was responsible for $37 \%$ of the region's total reduction in deforestation between 2004 and 2006 without provoking leakage [21]. If all planned and existing PAs [22] in the Brazilian Amazon were fully implemented, they could potentially avoid $8.0 \pm 2.8 \mathrm{Pg}$ of carbon emissions by 2050, thus indicating that PAs are an effective tool for forest conservation and reducing carbon emissions. However, those estimates include indigenous lands, which cover 21.7 per cent of Brazilian Amazon. Such areas are not actually PAs, as indigenous people can use their lands for agriculture and logging. Nevertheless, such areas have been more effective than PAs in avoiding deforestation [21].

The creation of indigenous lands is a prerogative of the federal government. All levels of government have the authority to establish traditional PAs in their own territory, either by purchasing private lands or by signing agreements with other levels of government to donate or receive their lands. Municipal governments, however, have few incentives and insufficient means to establish and manage PAs. Mayors in Amazonia tend to feel that land use restrictions limit economic development, with the local population paying the price of forest conservation. State governments, by contrast, are becoming prominent actors in this process. As shown in Figure 1, state governments had created about $50 \%$ of all PAs in the Brazilian Amazon in 2009. An analysis of the period 2003-2009 indicates that the role of the states has been increasing, with states having created $61 \%$ of the most recent PAs [23].

The period since 2003 is particularly significant because in that year Brazil elected a new president and all nine states in Amazonia elected their governors. Also in 2003, when the new governments were inaugurated, the ARPA Project was launched, which meant the federal government offered an incentive for any new governors who were willing to promote the protection and sustainable use of the forests in their states. From the outset, ARPA was designed to encourage interaction between the federal government, state governments and civil society organizations (WWF-Brasil, which provides technical support, and FUNBIO, which manages funds).

Figure 1. Protected areas in Amazonia.

Protected Areas in Amazonia Total in 2009 (HA)

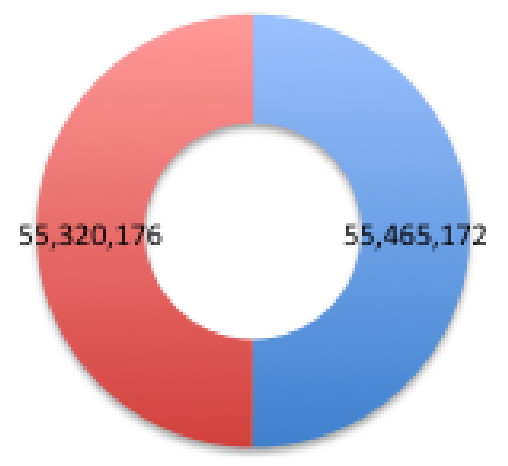

Protected Areas Created in Amazonia (HA) 2003 2009

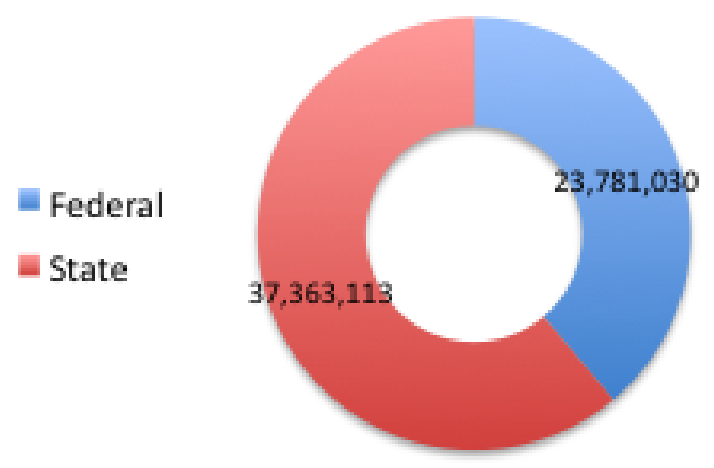


ARPA invested US\$ 105 million in the creation and consolidation of 63 PAs. As 42 of those are federal, the program clearly does not account for the increase in state PAs. State governments had to raise money elsewhere or allocate a larger share of their budgets to PAs. Their willingness to do so, or even to work with the federal government to receive ARPA funds, varied, as did the total area of PAs that each state created.

Figure 2 compares the contributions of Amazonian states to the total area of PAs created by state governments between 2003 and 2009. Two states_Amazonas and Pará-together account for nearly $90 \%$ of the total. Certainly, these are the two largest states in the country, but state size is not directly correlated with the area of PAs. From Table 2 and Figure 3, it is possible to see that some smaller states have a much higher proportion of PAs; for example, the smallest state, Amapá, has $62 \%$ of its lands under protection, a number slightly higher than that for the state of Roraima. Most PAs in those states are federal; their state governments were not very active in creating new PAs during the study period. An important explanation for this policy choice is that those states already had severe land use restrictions, with a large share of their forests already protected; hence, they did not see a need to create new PAs. Indeed, imposing further restrictions on land use could prove politically difficult for the governors.

Figure 2. Protected areas and indigenous lands in Amazonian states (\% of state surface).

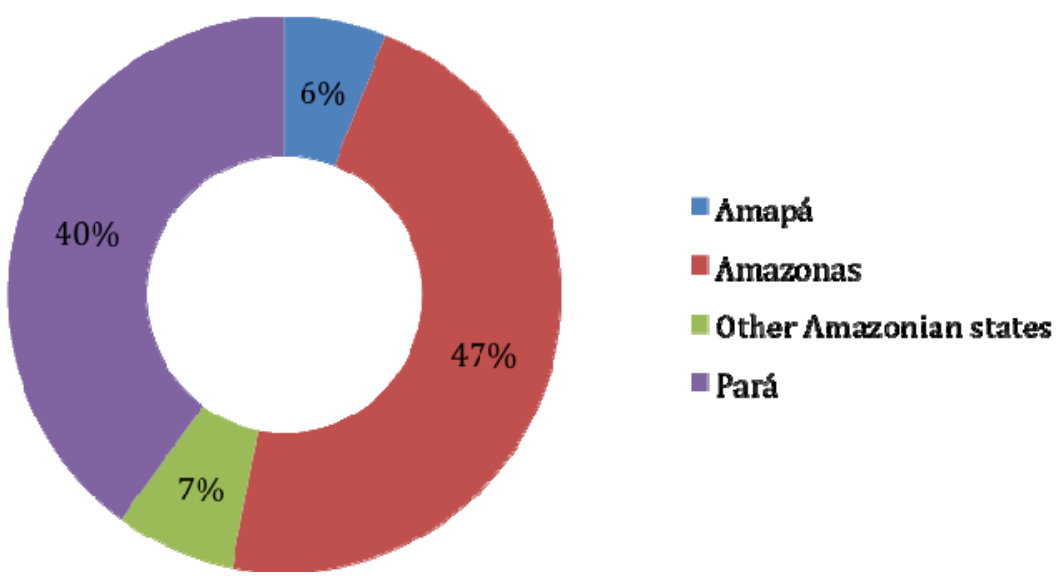

In some states, such as Acre, the government created significantly large PAs before 2003, and collaborated with the federal government in the creation of federal PAs. This collaboration arose as, at that time (1999), the state had little capacity to manage its forests and its government had been elected with the support of a coalition of small farmers, indigenous peoples and, particularly, rubber tappers [24]. Thus, the state government did not see the creation of federal PAs as an intervention, and sought help form the central government in order to protect the interests of its supporters. 
Table 2. Area and percentage of protected areas in Amazonian states.

\begin{tabular}{|c|c|c|c|c|c|c|c|c|}
\hline & \multirow{2}{*}{$\begin{array}{c}\text { Total state } \\
\text { area } \\
\mathbf{k m}^{2}\end{array}$} & \multicolumn{2}{|c|}{$\begin{array}{c}\text { Strict use } \\
\text { protected areas }\end{array}$} & \multicolumn{2}{|c|}{$\begin{array}{l}\text { Sustainable use } \\
\text { protected areas }\end{array}$} & \multicolumn{2}{|c|}{ Indigenous lands } & \multirow{2}{*}{$\begin{array}{l}\% \text { for } \\
\text { all PAs }\end{array}$} \\
\hline & & $\mathbf{k m}^{2}$ & $\%$ & $\mathbf{k m}^{2}$ & $\%$ & $\mathbf{k m}^{2}$ & $\%$ & \\
\hline Acre & 152,581 & 16,710 & 10.9 & 35,439 & 23.2 & 24,421 & 16 & 50.2 \\
\hline Amapá & 142,815 & 47,772 & 33.5 & 40,761 & 28.5 & 11,879 & 8.3 & 70.3 \\
\hline Amazonas & $1,570,746$ & 112,485 & 7.2 & 228,621 & 14.6 & 427,967 & 27.2 & 48.9 \\
\hline Maranhão & 249,632 & 13,401 & 5.4 & 722 & 0.3 & 22,584 & 9 & 14.7 \\
\hline Mato Grosso & 903,358 & 29,469 & 3.3 & 1,318 & 0.2 & 138,012 & 15.3 & 18.7 \\
\hline Pará & $1,247,690$ & 126,405 & 10.1 & 185,944 & 14.9 & 282,218 & 22.6 & 47.6 \\
\hline Rondônia & 237,576 & 19,902 & 8.4 & 41,421 & 17.4 & 48,629 & 20.5 & 46.2 \\
\hline
\end{tabular}

Figure 3. Area of protected and indigenous lands in Amazonian states $\left(\mathrm{km}^{2}\right)$.

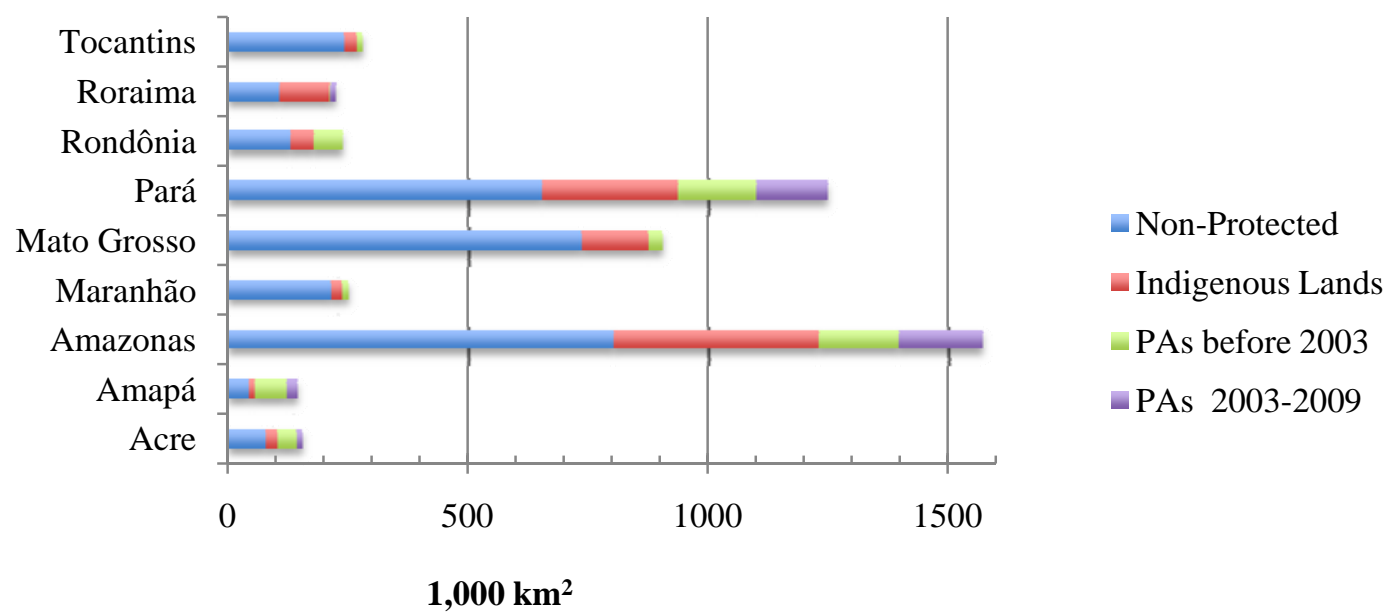

By contrast, the government of Mato Grosso has proven very reluctant to create PAs, largely because the state, although immense and the third largest in the country, has a considerably smaller forest area. Mato Grosso is at the heart of the Brazilian agricultural frontier, and leads the country in soybean and cattle production. Government policies are shaped not only by the relatively limited availability of forests, but also by the lack of political will to change the state's status as the 'bread basket of Brazil'. Mato Grosso had the highest deforestation rate in the country (about 6,200 $\mathrm{km}^{2} /$ year) between 2000 and 2009. The current governor is the single largest soybean producer in the world; he was elected in 2002 and again in 2006, with the full support of farmers and ranchers, who expected to encounter little resistance towards further agricultural expansion. Until very recently, neither the state government nor its constituency had many, if any, incentives to engage in forest protection. It is probable that, as they become aware of opportunities to profit from payments for environmental services or of the possibility of market sanctions for clearing forests, they will gradually change their behavior. 
The relatively small proportion of PAs in Mato Grosso reflects the resistance the federal government has encountered in its attempts to curb deforestation at the agricultural frontier. Although one might argue that the federal government has historically created PAs that are marginal to agriculture, the situation in Pará appears to contradict this point of view, or at least suggests a recent policy shift at both federal and state levels. Pará is second only to Mato Grosso in terms of deforestation and cattle ranching. However, there has been a political shift in the state since the 2006 election, with the government intensifying the creation of PAs. The federal government also paid more attention to the state, especially after the 2005 murder of missionary Dorothy Stang, in the wake of the violence, land grabbing and deforestation that followed the announcement that the BR-163 highway would be paved.

Amazonas experienced a political shift in 2002, and has since pursued an ambitious pro-forest agenda that has included not only the creation of many PAs, but also investment in industrial and community forest management, and use of non-timber forest products, amongst others [24]. Eighty per cent of the PAs created by the Amazonas state government fit in the sustainable use category, which indicates the government's attempt to protect forests without imposing severe land use restrictions on the local population. Although Pará has followed a similar path, most of its new PAs (53\%) are state forests, which can be put under either community or industrial forest management, according to the 2006 Forest Concession Law.

Considering that $74 \%$ of the global area put under protection since 2003 is in Brazil [19], it is clear that state-level policies in Brazil have been crucial for the protection of biodiversity and thus form an important variable for any mechanism designed to reduce carbon emissions by protecting tropical forests.

\section{Implications of Decentralization for REDD+}

The states' responsibilities concerning forests extend beyond the creation of PAs. Although historically the federal government has been responsible for controlling timber exploitation, tree felling and controlled burning, the past decade has seen increasing decentralization of these activities. The state of Amazonas, as part of its general shift towards improving the forestry sector, assumed responsibility for forest management and promptly simplified the bureaucratic process for issuing permits for small-scale and low-impact forest management. In other words, the government tried to legalize an important economic activity that was already carried out by much of the rural population. It also created incentives, such as credit and technical assistance, to increase income and to engage more rural dwellers in forestry. As decentralization evolved, the state government strengthened its forestry and environmental structure by creating new agencies and recruiting staff [24].

In a similar manner, but with different politics, the government of Mato Grosso assumed responsibility for some of IBAMA's functions and prioritized the creation of a state-wide land registry system and the licensing of agricultural activities. The government's intention was to legalize agricultural activities and reduce deforestation, with the expectation that the move would benefit ranchers and farmers by providing conditions for them to access new markets and to receive payments for ecosystem services. 
Even municipal governments are now attempting to make farmers and ranchers in their territories comply with environmental laws, foreseeing not only the benefits discussed above, but also the possibility of being punished in the short term through market mechanisms for fostering deforestation (see Box 2).

Box 2. Municipalities step in: the Lucas do Rio Verde Project.

Lucas do Rio Verde is a prosperous municipality in northern Mato Grosso, in a transition zone between the Cerrado (Brazilian central savannahs) and Amazonia.

The Forest Code requires that farmers in this area preserve riparian forests and set aside 35\% of their forests as 'Reserva Legal'. However, most of Lucas do Rio Verde’s forests were cleared long ago, and the municipality is now one of the largest soy producers in Brazil. A few years ago, during a trip to Germany, the mayor learned that some consumers were boycotting Brazilian beef because ranching is the most important driver of deforestation (Ferreira in press). Realizing the major blow that market sanctions could deal to Brazilian agribusiness, he decided to take action.

The municipal government sided with food and pesticide giants Sadia and Syngenta, with the mayor's trading company Fiagril, and sought support from The Nature Conservancy (TNC) to have all farmers comply not only with the Forest Code, but also with other environmental and labor legislation. As a result, the municipality produced its own land registry, mapped all areas originally covered with riparian forests and successfully engaged farmers in the recovery of those areas. As for the Reserva Legal areas, farmers will compensate for deforestation by collectively buying a forest area elsewhere, which will be put under strict protection.

Lucas do Rio Verde is now waiting for legal approval from the state environmental authorities to close the deal and will likely become the first municipality on the agricultural frontier to comply with Brazil’s demanding Forest Code [25].

The case of Lucas do Rio Verde and the overall political shift in Mato Grosso's environmental policies are examples of how market mechanisms can change the incentive structure for both farmers and politicians. However, they also contribute to the debate concerning the theoretical benefits of decentralization. Although the Mato Grosso state government has successfully sought power over forest policies during the past decade, this decentralization has not resulted in further protection of the forest. Rather, the government has made considerable efforts to deregulate land use, increase transportation infrastructure and develop agribusiness in the state.

Centralized control of indigenous lands, by contrast, has effectively protected both immense territories and the livelihoods of peoples who would probably be expelled from their lands if left to the state or municipal governments. In some cases, the federal government has ensured the protection of local people by creating extractive reserves, which protected rubber tappers and nut gatherers against encroaching ranchers and loggers. In other cases, however, the creation of restricted use PAs has led to heavy burdens for local people.

REDD+ money could potentially solve many of the problems surrounding the establishment of PAs and indigenous lands. Although indigenous lands are not PAs and indigenous people are not obliged to 
keep forests intact, they usually do so; however, many live in severe poverty and face serious health problems. FUNAI, the federal agency in charge of indigenous affairs, is understaffed and its employees underpaid. Furthermore, independent gold and diamond miners, loggers, ranchers and farmers frequently encroach upon indigenous lands near the agricultural frontier. REDD+ resources could help provide indigenous people with better public services and effective land protection.

Similar factors hamper the full implementation of PAs. Most parks in Brazil are closed to the public because of the lack of infrastructure and staff. As of July 2008, 210 out of 299 federal PAs (excluding indigenous lands) did not have, management plans, which are required by law. Also, 184 did not have management boards - another legal requirement. ICMBIO classified the existing infrastructure as insufficient in 43 PAs and reported that 161 had no infrastructure at all. About 75\% of the PAs were in the early stages of implementation. A recent study estimated that federal government alone would need to invest about US\$ 440 million to consolidate the existing federal PAs, and spend about US\$ 46 million/year to maintain those areas [26].

Extractive reserves are subject not only to encroachments from outsiders, but also to deforestation by their own inhabitants, who cannot make a living selling nuts and rubber and so resort to cattle ranching to make ends meet [27]. Sustainable forest management is still too expensive for small-scale operations. The governments of Acre and Amazonas have created some subsidies to increase forest people's income so they can avoid clearing the forest or migrating to urban areas. However, resources are insufficient to meet the needs of all the rural poor.

REDD+ money may be a valuable resource to bolster redistributive programs, which in turn aim to reduce deforestation. However, increasing the income of some sectors of the rural population alone will not control deforestation. In fact, this kind of policy can backfire, for they can also induce investments in agriculture and ranching. According to a recent study, in Acre [28], the implementation of the subsidy through 2002 showed that its distribution had been fairly concentrated and correlated with ownership and sale of cattle. Even though income transfers to the poorest strata of the rural population is desirable, other policies will be needed to protect the forest.

A rough estimate indicates that a massive 10 year program aimed at ending deforestation in the Amazon would cost US\$ 7 billion to US\$ 18 billion. Such a program would have to include the establishment of PAs, compensation for reduced deforestation in private properties, investments in law enforcement, investments in sustainable forest management, and other activities. That cost would be easily covered by a REDD+ system, as designed in the American Clean Energy Security Act passed by the U.S. House of Representatives, which could generate US\$ 37 billion to US\$ 111 billion between 2013 and 2020 [2]. It is doubtful, however, that an influx of money alone would result in sound policies. The Brazilian state is known for its inefficiency in public spending. The Ministry of Environment, in 2008 spent only 49\% of its approved budget [29]. Unfortunately, there is no data available on the spending capacity of state and municipal governments. It seems, however, that if the optimistic REDD+ scenarios come true, the federal government will have to increase its efficiency in spending and count on the help of subnational governments to implement the policies required to decrease deforestation. 


\section{State Governments and REDD+: Mutual Benefits?}

Brazilian states are becoming increasingly involved in the management of their forests. They are developing the capacity to use and protect forests and are becoming more interested in doing so, in response to pressures and incentives coming both from above (federal government, donors and markets) and from below (their constituents). Brazil's federal system grants governors the political power to negotiate significant participation in future REDD+ mechanisms. As the above discussion makes clear, the governors are well positioned to claim such participation, as they are responsible for a large share of PAs in Amazonia and are becoming increasingly involved in licensing, forest management and law enforcement.

Also important are governors' recent direct measures concerning carbon emissions and REDD+. The governors of no fewer than five Amazonian states-Acre, Amapá, Amazonas, Mato Grosso and Pará-are members of the Governors' Climate and Forests Task Force (GCF), a subnational collaborative group comprising 14 states and provinces from the United States, Brazil, Indonesia, Nigeria and Mexico. The GCF seeks to integrate REDD+ and other forest carbon activities into emerging greenhouse gas compliance regimes. One of its main goals is to develop institutions and programs for linking subnational REDD activities with ongoing national and international efforts. In their own words, 'GCF members want to be early movers on the effort to bring REDD into climate policy ...’ [30].

Even more important, however, was the domestic mobilization of the governors, who, in 2009, took the lead in the discussion of a national REDD+ policy. After a meeting of the governors of all nine Amazonia states, they sent a letter to the president, pointing out that Brazil was lagging behind other developing countries in the carbon market. They argued that if Brazil was to receive more funds from carbon credits and to reduce its own carbon emissions, REDD+ mechanisms had to be included in the international carbon market, under the U.N. Framework Convention on Climate Change (UNFCCC). It is no coincidence that this effort came a few months before the UNFCCC 15th Conference of the Parties (COP 15).

In their letter, the governors sought the creation of: (1) A task force consisting of representatives from federal and state governments; (2) a federal office to coordinate the development, implementation and management of a National Emission Reduction System, which would coordinate and support federal, state and municipal governments; and (3) an Amazonian Governors Committee to take part in COP 15 alongside the president. Their requests were partially met: The task force was formed and governors from Amazonian states went to COP 15, but as of mid-2010, no new federal office had been created to coordinate action. However, the Ministry of the Environment assumed responsibility for discussions on REDD+, under the leadership of a market and finance expert. This was no minor achievement for the governors because, until then, the Environment and Foreign Relations Ministries had been opposing the use of market-based compensatory mechanisms to curb deforestation.

\section{Conclusions and Recommendations}

Brazil has been experiencing a slow but steady process of decentralization of forest policies. This trend will certainly affect and be affected by the influx of financial resources likely to result from 
REDD+ agreements. Although central authorities may be tempted to centralize control over responsibilities and resources, the very nature of Brazilian federalism grants governors sufficient powers to avoid this. Moreover, it is clear that, if Brazil is to reduce deforestation and protect biodiversity, the central government will need help from the states, which are already actively involved in the creation of PAs. In this sense, decentralization is likely to benefit from the implementation of REDD+ in Brazil.

State governments will be major players in REDD+ mechanisms in Brazil. However, it is currently unclear whether municipal governments will also benefit from REDD+ resources. Unlike state governments, they have not been motivated to get involved in this potential carbon market. Nonetheless, some municipalities do have the capacity to engage in forest protection if they obtain the means to do so.

From the outset, discussions about REDD+ in Brazil have involved both federal and state governments. These early attempts to find common ground may reduce the likelihood of conflict if and when resources start flowing into the country. The very nature of REDD+ mechanisms requires the central government to assume key responsibilities in the control of deforestation, but it will have to support some policies implemented at the state level. In this sense, REDD+ may represent a unique opportunity to further entrench decentralization. To date, decentralization of forest policies in Brazil has been voluntary, at the demand of state governments. However, the availability of considerable financial resources might encourage the federal government to work with the states to devise a fully funded decentralization program.

Although Brazil has made remarkable progress in creating PAs in the past eight years, with considerable participation by the state governments, the future protection of forests cannot be taken for granted. Encroachments on PAs and indigenous lands are frequent. Deforestation rates remain high and vulnerable to market forces. Law enforcement at both federal and state levels is weak, and environmental agencies at all levels are understaffed. Brazil and the Amazonian states should not wait for REDD+ money to solve these problems. Rather, they should immediately increase their investment in institutional capacity building to ensure they are ready to manage REDD+ money when (or if) it becomes available. Similarly, the federal government should consider REDD+ as just one part of an overall strategy to reduce carbon emissions.

Governments-federal, state or municipal—should be seen not as the beneficiaries of REDD+, but rather as the means to channel resources to whichever stakeholders act as forest guardians. Included among such actors are government agencies. Given that indigenous people own much of the protected land in Amazonia, they should be part of REDD+ negotiations, as should rubber tappers, small-scale farmers, river dwellers and other traditional forest peoples.

\section{Acknowledgments}

The author would like to thank Anne Larson, Elena Petkova, Isadora Ferreira and two anonymous reviewers for their comments and suggestions, as well as Edith Johnson and Gideon Suharyanto for their editorial support. 


\section{References and notes}

1. Santilli, M.; Moutinho, P.; Schwartzman, S.; Nepstad, D.; Curran; L.; Nobre, C. Tropical deforestation and the Kyoto Protocol: An editorial essay. Climatic Change 2005, 71, 267-276.

2. Nepstad, D.; Soares-Filho, B.S.; Merry, F.; Lima, A.; Moutinho, P.; Carter, J.; Bowman, M.; Cattaneo, A.; Rodrigues, H.; Schwartzman, S.; et al. The end of deforestation in the Brazilian Amazon. Science 2009, 326, 1350-1351.

3. Phelps, J.; Webb, E.L.; Agrawal, A. Does REDD+ threaten to recentralize forest governance? Science 2010, 328, 312-313.

4. Irawan, S.; Tacconi, L. Reducing emissions from deforestation and forest degradation (REDD) and decentralized forest management. Int. Forest. Rev. 2010 11, 427-438, doi:10.1505/ifor.11.4.427.

5. Rondinelli, D. Government decentralization in comparative perspective: theory and practice in developing countries. Int. Rev. Adm. Sci. 1981, 2, 133-145.

6. Parker, A. Decentralization: The Way Forward for Rural Development? Policy Research Working Paper 1475; World Bank: Washington, DC, USA, 1995.

7. Manor, J. The Political Economy of Democratic Decentralization; World Bank: Washington, DC, USA, 1999.

8. Ribot, J.C. Waiting for Democracy: The Politics of Choice in Natural Resource Decentralization; World Resources Institute: Washington, DC, USA, 2004.

9. Toni, F.; Kaimowitz, D. O papel dos municípios na gestão florestal: lições dos estudos de caso. In Municípios e gestão florestal na Amazônia; Toni, F., Kaimowitz, D., Eds.; A.S. Editores: Natal, Brazil, 2003; pp. 23-63.

10. Toni, F.; Pacheco, P. Gestão ambiental descentralizada: um estudo comparativo de três municípios da Amazônia Brasileira; Ministério do Meio Ambiente: Brasília, Brazil, 2005.

11. Valle, R.S.T.; Yamada, E.M. Brasil: Titularidade Indígena sobre Créditos de Carbono gerados por Atividades Florestais em Terras Indígenas. Parecer Jurídico sobre a titularidade de Créditos de Carbono gerados por atividades florestais em Terras Indígenas no Brasil; Instituto Socioambiental: Brasília, Brazil, 2010.

12. Nepstad, D.; Schwartzman, S.; Bamberger, B.; Santilli, M.; Ray, D.; Schlesinger, P.; Lefebvre, P.; Alencar, A.; Prinz, E.; Fiske, G.; Rolla, A. Inhibition of Amazon deforestation and fire by parks and indigenous lands. Conserv. Biol. 2006, 20, 65-73.

13. Larson, A.M.; Ribot, J.C. Lessons from forestry decentralisation. In Realising REDD+: National Strategy and Policy Options; Angelsen, A., Brockhaus, M., Kanninen, M., Sills, E., Sunderlin, W.D., Wertz-Kanounnikoff, S., Eds.; CIFOR: Bogor, Indonesia, 2009; pp. 175-187.

14. Nickson, R.A. Local Government in Latin America; Lynne Rienner Publishers: Boulder, CO, USA and London, UK, 1995.

15. Stepan, A. Para uma nova análise comparativa do federalismo e da democracia: federações que restringem ou ampliam o poder do demos. Dados 1999, 42, 197-251.

16. Abrucio, F.L. Os barões da federação e a redemocratização Brasileira; Hucitec: São Paulo, Brazil, 1998. 
17. Article 23 of the Constitution lists as state duties the protection of sites of scenic beauty and archaeological sites (point III); environmental protection and the fight against contamination (point VI); preservation of forests, fauna and flora (point VII); and the registry, follow-up and inspection of water and mineral resources (point XI). Article 24 deals with urban planning rights (point I); forests, hunting, fishing, fauna, natural conservation, defence of the soil and natural resources, environmental protection and control of contamination (point VII); landscape patrimony (point VII); and responsibility for damage to the environment (point VIII).

18. Hochstetler, K.; Keck, M.E. Greening Brazil: Environmental Activism in State and Society; Duke University Press: Durham, NC, USA, 2007.

19. Jenkins, C.N.; Joppa, L. Expansion of the global terrestrial protected area system. Biol. Cons. 2009, 142, 2166-2174.

20. Ferreira, L.V.; Venticinque, E.; Almeida, S. O desmatamento na Amazônia e a importância das áreas protegidas. Estud. Av. 2005 19, 157-166.

21. Soares-Filho, B.; Moutinho, P.; Nepstad, D.; Anderson, A.; Rodrigues, H.; Garcia, R.; Dietzsch, L.; Merry, F.; Bowman, M.; Hissa, L.; et al. Role of Brazilian Amazon protected areas in climate change mitigation. Proc. Natl. Acad. Sci. USA 2010, 107, 10821-10826.

22. Brazilian protected areas (PAs) are divided in two groups: strict use PAs and sustainable use PAs. Strict use PAs aim to preserve nature and, therefore, allow only indirect use of natural resources. There are five categories of strict use PAs: ecological stations and biological reserves, in which only scientific and educational activities are allowed, and national parks, natural monuments and wildlife refuges, which also allow public access. Sustainable use PAs aim to reconcile conservation and sustainable use of natural resources. There are seven categories of sustainable use PAs, including extractive reserves and national forests, which together comprise the largest share of sustainable use PAs in Brazilian Amazon. Residents of extractive reserves can manage the forest for timber and non-timber products and can manage small agricultural plots. Cattle ranching is illegal in such areas.

23. Data shown on Figures 1-3 and on Table 2 draw on data obtained from Instituto Socioambiental, and refer to area of PAs as of 2009. Data discount overlaps between PAs. Available online: http://www.socioambiental.org/loja/detalhe_produto.html?id_prd=10333 (accessed on 1 August 2010)

24. Toni, F. Gestão florestal na Amazônia brasileira: avanços e obstáculos em um sistema federalista; CIFOR: Bogor, Indonesia, 2006.

25. Ferreira, I.N.R. Parcerias para a gestão ambiental em propriedades rurais: O caso de Lucas do Rio Verde-MT; Centro de Desenvolvimento Sustentável, Universidade de Brasília: Brasília, Brazil, 2010.

26. Muanis, M.M. Quanto custa uma unidade de conservação federal? : uma visão estratégica para o financiamento do Sistema Nacional de Unidades de Conservação (Snuc); Funbio: Rio de Janeiro, Brazil, 2009.

27. Toni, F.; Santos, J.C.; Menezes, R.S.; Wood, C.H.; Sant’Ana, H. Expansão e trajetórias da pecuária na Amazônia: Acre, Brasil; Editora UnB: Brasília, Brazil, 2007.

28. Sillsa, E.; Shubhayu, S. Subsidies for rubber: Conserving rainforests while sustaining livelihoods in the Amazon? J. Sustain. Forest. 2010, 29, 152-173. 
29. MINISTÉRIO DO MEIO AMBIENTE. Pilares para a Sustentabilidade Financeira do Sistema Nacional de Unidades de Conservação; Ministério do Meio Ambiente: Brasília, Brazil, 2009.

30. GCF. Governors' Climate and Forests Taskforce homepage. Available online: http://gcftaskforce.org/index.html (accessed on 2 June 2010).

(C) 2011 by the authors; licensee MDPI, Basel, Switzerland. This article is an open access article distributed under the terms and conditions of the Creative Commons Attribution license (http://creativecommons.org/licenses/by/3.0/). 